Magdalena Kamińska, Magdalena Hartman-Petrycka,

Małgorzata Bożek, Beata Krusiec-Świdergot, Maria Nędza, Stawomir Wilczyński

\title{
ASSESSMENT OF KNOWLEDGE AND SELECTED ATTITUDES AMONG SILESIANS ABOUT EFFECTS OF ULTRAVIOLET RADIATION ON HEALTH
}

\author{
DIAGNOZA WIEDZY I WYBRANYCH POSTAW MIESZKAŃCÓW \\ WOJEWÓDZTWA ŚLĄSKIEGO NA TEMAT WPŁYWU PROMIENIOWANIA \\ ULTRAFIOLETOWEGO NA STAN ZDROWIA
}

\author{
Department of Basic Biomedical Sciences, \\ School of Pharmacy with the Division of Laboratory Medicine in Sosnowiec, \\ Medical University of Silesia, Katowice, Poland \\ Katedra i Zakład Podstawowych Nauk Biomedycznych, \\ Wydział Farmaceutyczny z Oddziałem Medycyny Laboratoryjnej w Sosnowcu, \\ Śląski Uniwersytet Medyczny w Katowicach
}

\begin{abstract}
INTRODUCTION. Both insufficient and excessive exposure to UV radiation (UVR) lead to serious health consequences: Caucasian people living in northern Europe commonly suffer from vitamin D deficiencies, constant increasing number of melanoma incidents is alarming.

AIM. Assessment of knowledge and selected attitudes among Silesians about ultraviolet radiation.

MATERIAL AND METHODS. Study involved 169 adult residents of the one Silesian city. The original, anonymous questionnaire containing 25 questions about UVR was used. Respondents ( 85 females, 84 males) of different age and level of education were examined.

RESULTS. One-third of respondents do not spend time outdoors during sunny weather. The solarium is used by $9 \%$ of the studied group. The vitamin D synthesis was a favorable UV effect known by $90 \%$ of the respondents. $51 \%$ of the group did not know about the UV importance in melanin synthesis. 55\% of respondents were not aware of the significance of the SPF (Sun Protective Factor) abbreviation, and $40 \%$ of people with the vocational education were convinced that the SPF50+ provides complete sun protection. Only $44 \%$ of women and $23 \%$ of men differentiated basic skin phototypes. Respondents knew at what time of a day in spring-summer the sun should be avoided, $71 \%$ knew about the re-application of a waterproof sunscreens after bath. $64 \%$ of women and $37 \%$ of men presented the sufficient knowledge of melanoma. Only $38 \%$ of respondents paid attention to UV filters when buying sunglasses.

CONCLUSIONS. Respondents were aware of the UVR value for the vitamin D synthesis, but only a small percentage declared short-term sun exposures. Women had more knowledge about negative effects of UVR. People over 50 years of age and those with vocational education had a limited knowledge about health effects of UVR.
\end{abstract}

Key words: vitamin $D$, ultraviolet radiation, tanning, photoprotection

\section{STRESZCZENIE}

WPROWADZENIE. Niedostateczna, jak również nadmierna ekspozycja na promieniowanie ultrafioletowe niesie za sobą duże konsekwencje zdrowotne: u osób rasy kaukaskiej zamieszkujących Europę północną występują powszechnie niedobory witaminy D i alarmują wzrastające statystyki zachorowalności na czerniaka złośliwego. CEL. Ocena stanu wiedzy, opinii oraz niektórych zachowań mieszkańców woj. śląskiego dotyczących promieniowania ultrafioletowego.

MATERIAŁ I METODY. Badanie przeprowadzono wśród 169 dorosłych mieszkańców jednego z miast w województwie śląskim przy użyciu autorskiej, anonimowej ankiety zawierającej 25 pytań dotyczących promieniowania UV. Respondenci (85 kobiet i 84 mężczyzn) różnili się wiekiem i posiadanym wykształceniem.

WYNIKI. Jedna trzecia badanych nie spędza czasu na wolnym powietrzu w czasie słonecznej pogody. $Z$ solarium

(C) National Institute of Public Health - National Institute of Hygiene / Narodowy Instytut Zdrowia Publicznego - Państwowy Zakład Higieny 
korzysta 9\% badanej grupy. Korzystnym skutkiem UV, który znało 90\% ankietowanych była synteza witaminy D. $51 \%$ grupy nie wiedziało o funkcji UV w syntezie melaniny. 55\% badanych nie znało znaczenia skrótu SPF (Sun Protective Factor), a 40\% osób z najniższym wykształceniem było przekonanych, że czynnik SPF50+ pozwala na bezpieczne opalanie. Zaledwie $44 \%$ kobiet i $23 \%$ mężczyzn rozróżniało podstawowe fototypy skóry. Respondenci wiedzieli, w jakich godzinach należy unikać słońca w okresie wiosna-lato, a 71\% wiedziało o ponownym użyciu kosmetyku wodoodpornego po kąpieli. Prawidłową wiedzę na temat czerniaka posiadało $64 \%$ kobiet i 37\% mężczyzn. Tylko $38 \%$ badanych zwracało uwagę na filtry przeciw UV przy zakupie okularów przeciwsłonecznych.

WNIOSKI. Respondenci wiedzieli, że promieniowanie UV jest niezbędne do syntezy witaminy D, lecz tylko niewielki ich procent deklarował krótkie ekspozycje słoneczne. Kobiety miały większą wiedzę na temat niekorzystnych skutków promieniowania UV. Najmniejszą wiedzą dotyczącą wpływu promieniowania UV na zdrowie dysponowały osoby po 50 roku życia i z wykształceniem zawodowym.

Słowa kluczowe: witamina D, promieniowanie ultrafioletowe, opalanie, fotoprotekcja

\section{INTRODUCTION}

Ultraviolet is a part of the optical radiation with a wavelength from 100 to $400 \mathrm{~nm}$. According to partition proposed in Copenhagen in 1932, it is divided into three main ranges depending on the wavelength: UVC (100-280), UVB (280-315) and UVA (315-400). The second division, slightly different from the previous one: UVC (200-290), UVB (290-320), UVA (320400), has been designated by photobiologists based on the interaction of radiation range with biological materials. Only part of the ultraviolet spectrum reaches the earth's surface (95\% UVA and 5\% UVB), because waves of less than $290 \mathrm{~nm}$ length are absorbed by the ozone layer. Increased UV exposure occurs along with the lower latitude (the closer the equator the higher the radiation levels), the higher the sun above the horizon and the higher altitude above the sea. However, at cloudy days or along with high air pollution levels (for example smog) the impact of UVR on human body decreases (1).

The most well-known beneficial effect of ultraviolet with a wavelength below $320 \mathrm{~nm}$ (UVB) is the initiation of vitamin D synthesis in epidermal cells, being a precursor of calcitriol $-1.25(\mathrm{OH})_{2} \mathrm{D}_{3}$ formed in kidney. The active form of vitamin $\mathrm{D}$ is responsible for maintaining calcium and phosphate levels for normal bone formation, development and mineralization. Receptors for vitamin $D$ has been found in almost every cell of the human body including most of the immune system cells. Vitamin D also plays a crucial role in the regulation of cell proliferation, differentiation and apoptosis. According to epidemiological studies, over half of the Europeans suffer from a low vitamin D levels. It is a result of the increasing average of time spending indoors, sun avoidance and excessive photoprotection. Vitamin D deficiency $(<25 \mathrm{nmol} / \mathrm{l})$ in children results in increased risk of rickets as well as osteoporosis and osteomalacia in adults. There are also studies showing the relationship between low vitamin D levels and cardiovascular diseases (hypertension,

\section{WSTĘP}

Promieniowanie ultrafioletowe jest częścią promieniowania optycznego o długości fali mieszczącej się w przedziale $100-400 \mathrm{~nm}$. Zgodnie z podziałem zaproponowanym w Kopenhadze w 1932 roku dzieli się ono na trzy główne zakresy w zależności od długości fali: UVC (100-280), UVB (280-315) i UVA (315-400). Drugi podział, stosowany przez fotobiologów, nieznacznie różni się od poprzedniego: UVC (200-290), UVB (290-320) i UVA (320-400) i związany jest $z$ różnym oddziaływaniem biologicznym poszczególnych zakresów. Fale o długości poniżej $290 \mathrm{~nm}$ są zatrzymywane przez warstwę ozonową atmosfery, więc do powierzchni ziemi dociera tylko cześć widma ultrafioletu emitowanego przez słońce (95\% UVA i 5\% UVB). Do zwiększonej ekspozycji na promieniowanie UV dochodzi wraz ze zmniejszającą się szerokością geograficzną (im bliżej równika, tym natężenie promieniowania jest większe), zwiększającą się wysokością słońca nad horyzontem i zwiększającą się wysokością nad poziomem morza. Do zmniejszenia oddziałującej na organizmy dawki promieniowania UV przyczynia się natomiast zachmurzenie i zanieczyszczenie powietrza (np. smog) (1).

Najlepiej poznanym, korzystnym działaniem ultrafioletu o długości fali poniżej $320 \mathrm{~nm}$ (UVB) jest zapoczątkowanie w komórkach naskórka syntezy witaminy $\mathrm{D}$, będącej prekursorem powstającego w nerkach kalcytriolu - $1,25(\mathrm{OH})_{2} \mathrm{D}_{3}$. Aktywna postać witaminy D odpowiada za utrzymanie prawidłowej gospodarki wapniowo-fosforanowej $\mathrm{w}$ organizmie, jest niezbędna $\mathrm{w}$ procesie mineralizacji oraz podczas prawidłowego wzrostu i rozwoju kości. Obecność receptorów dla witaminy D stwierdzono niemal w każdej komórce ciała ludzkiego łącznie z większością komórek układu immunologicznego. Witamina D odgrywa ponadto ważną rolę w regulacji proliferacji komórkowej oraz w procesie różnicowania komórek i ich apoptozy. Według badań epidemiologicznych ponad połowa populacji Europy cierpi na niedobory tej witaminy w organizmie. Sytuacja ta wynika z wydłużenia czasu spędzanego w ciągu dnia w pomieszczeniach zamknię- 
coronary artery disease), autoimmune diseases (type I diabetes, multiple sclerosis) and some cancers (breast, prostate, colon) $(2,3)$.

Frequent and prolonged exposures to solar UVR are a serious threat for human health since tanning became fashionable and people, especially those with fair complexion, started to migrate to high solar radiation regions. The skin damage effect of UVA and $\mathrm{UVB}$, due to different wavelength, is achieved through different mechanisms. The energy from UVB radiation is absorbed directly by epidermal cells causing DNA photodamages. UVAradiation is less genotoxic, however its intensity is equal at particular location regardless of the season and daytime. It also can penetrate clouds and glass. Melanin and porphyrins absorb UVA radiation and form free radicals that cause DNA oxidative damage. The photodamaged genetic material may lead to skin cancer. Basal cell carcinoma is the most common of malignant skin cancers. Squamous cell carcinoma, the second most common form of skin cancer, is more invasive and has a tendency towards infiltration and metastasis. Malignant melanoma represents a $1.5-2 \%$ of all skin cancers and has the highest mortality rate due to late detection is responsible for $80 \%$ of all skin cancer-related deaths. Epidemiological studies indicate that the number of new cases of malignant melanoma among Caucasians increases by an average of 5\% each year, while among black people remains stable. The major risk factor of developing a malignant melanoma, specified by the International Agency for Research on Cancer - IARC, is exposure to UVR from sunlight. In 2009, WHO and IARC have also classified the use of UV-tanning devices (solariums) into the group of high risk factors $(4,5)$.

Due to large health consequences from both insufficient and excessive exposure to UVR, it was reasonable to examine the current state of knowledge, opinions and behaviors of Silesians regarding UVR. The another aim of this study was to indicate which group, regarding gender, age and level of education, has the better knowledge in this topic, and toward which groups, education programs should be directed.

\section{MATERIAL AND METHODS}

The study was conducted in 2017 on 169 residents of one of Silesian cities. Detailed characteristic of the studied group is presented in table 1. The method of a diagnostic survey with original, anonymous questionnaires was used in this study. The first part of the questionnaire consisted of questions about the gender, age and level of education. To determine a dose of UVR, respondents were asked if they spend time outdoors in sunny weather and use a solarium. Positive respondents were requested to provide the frequency and the length tych lub też celowego unikania słońca i nadmiernej fotoprotekcji. Niedobór witaminy D ( $<25 \mathrm{nmol} / \mathrm{l})$ skutkuje zwiększeniem ryzyka rozwoju krzywicy u dzieci oraz osteoporozy i osteomalacji u osób dorosłych. Istnieją również badania wskazujące na związek pomiędzy niskim stężeniem witaminy D a występowaniem chorób układu sercowo-naczyniowego (nadciśnienie tętnicze, choroba wieńcowa), chorób autoimmunologicznych (cukrzyca typu I, stwardnienie rozsiane) oraz niektórych nowotworów (sutka, prostaty, okrężnicy) $(2,3)$.

Zbyt częsta i długotrwała ekspozycja skóry na promieniowanie UV, wynikająca z panującej od kilkudziesięciu lat mody na opaleniznę, jak również migracja w rejony o dużym nasłonecznieniu, zwłaszcza przez osoby o jasnej karnacji stanowi poważne zagrożenie dla zdrowia i życia człowieka. Ze względu na różną długość fali, UVA i UVB doprowadzają do uszkodzeń skóry na drodze dwóch różnych mechanizmów. Energia promieniowania UVB pochłaniana jest bezpośrednio przez DNA komórek naskórka powodując fotouszkodzenia w materiale genetycznym. Promieniowanie UVA charakteryzuje się dużo słabszym działaniem genotoksycznym, jednakże jego natężenie $\mathrm{w}$ danym miejscu na powierzchni ziemi jest stałe niezależnie od pory roku oraz dnia. Przenika również przez chmury i szyby. W wyniku pochłaniania UVA przez melaninę i porfiryny dochodzi do powstawania wolnych rodników wywołujących oksydacyjne uszkodzenia DNA. Powstające fotouszkodzenia w materiale genetycznym komórek mogą prowadzić do rozwoju nowotworów skóry. Najczęściej spotykanym nowotworem złośliwym skóry jest rak podstawnokomórkowy. Drugi pod względem częstości występowania, rak kolczystokomórkowy, charakteryzuje się większą złośliwością objawiającą się skłonnością do naciekania i przerzutów. Czerniak złośliwy stanowi 1,5-2\% wszystkich nowotworów złośliwych skóry i cechuje go najwyższy odsetek umieralności - 80\% przypadków w wyniku zbyt późnego wykrycia nowotworu kończy się zgonem. Badania epidemiologiczne wskazują, że liczba nowych przypadków zachorowań na czerniaka złośliwego wśród przedstawicieli rasy kaukaskiej wzrasta średnio o 5\% rocznie, podczas gdy u osób rasy czarnej pozostaje na stałym poziomie. Głównym czynnikiem ryzyka rozwoju czerniaka uznanym przez Międzynarodową Agencję Badań nad Rakiem - IARC (International Agency for Research on Cancer) działająca przy WHO jest naturalne źródło UV - promieniowanie słoneczne. W 2009 roku WHO i IARC do grupy czynników najwyższego ryzyka zakwalifikowały również promieniowanie ultrafioletowe emitowane przez sztuczne źródła - solaria $(4,5)$.

$Z$ uwagi na duże konsekwencje zdrowotne wynikające zarówno z niedostatecznej, jak również nadmiernej ekspozycji na promieniowanie UV zasadne było zbadanie stanu wiedzy, opinii oraz niektórych zachowań mieszkańców województwa śląskiego dotyczących promieniowania 
of the UV exposure. The frequency of using sunscreens was also asked. The further part of the questionnaire consisted of 11 single choice questions, 4 multiple choice questions and two free text questions (about major sources of knowledge about UVR and about the most important criteria for purchasing sunglasses). Survey contained questions about basic differences between UVA and UVB, positive and negative effects of UVR and sun protection. Descriptive statistics were used in the analysis. The results were shown using a percentage scale. The percentage value was calculated in relation to the total number of answers given by the respondents to particular question. The $\mathrm{chi}^{2}\left(\chi^{2}\right)$ test of independence was used for statistical analysis. Statistical significance was set at the $\mathrm{p} \leq 0.05$ level.

Table I. Participant characteristics $(\mathrm{N}=169)$

Tabela I. Charakterystyka badanej grupy $(\mathrm{N}=169)$

\begin{tabular}{|c|c|c|c|}
\hline \multirow{2}{*}{ gender } & & $\mathrm{n}$ & $\%$ \\
\hline \multirow{3}{*}{ age } & females & 85 & 50,3 \\
\cline { 2 - 4 } & males & 84 & 49,7 \\
\hline \multirow{3}{*}{ level of education } & $20-35$ & 74 & 43,8 \\
\cline { 2 - 4 } & $36-50$ & 48 & 28,4 \\
\cline { 2 - 4 } & $51-70$ & 47 & 27,8 \\
\cline { 2 - 4 } & higher & 60 & 35,5 \\
\cline { 2 - 4 } & secondary & 89 & 52,7 \\
\cline { 2 - 4 } & vocational & 20 & 11,8 \\
\hline
\end{tabular}

\section{RESULTS}

$34 \%$ of the surveyed group (58 people) declared not spending time outdoors durin $g$ sunny weather in spring and summer. The majority of the rest of the group (111 people; 48 male and 63 female) sunbathe only during the holiday period. 4 people spend about 30 minutes a day in the sun, a further 4 people about 1 hour a day, and for one person it was up to 6 hours a day, which could be related to the specific type of ones work. In the study group, 16 people (9\%) use the solarium (4 men and 12 women) $(p<0.05)$. Cosmetics with sunscreens were used by a larger number of women than men. The percentage of women and men using such cosmetics with specific frequency, amounted respectively: for always $8 \%$ and $0 \%$; often $39 \%$ and $5 \%$; rarely $50 \%$ and $85 \%$; never $3 \%$ and $10 \%$.

The respondents were asked about the knowledge of the positive effects of UVR on the skin. $88 \%$ of men and $92 \%$ of women indicated the vitamin D synthesis. The frequency of such responses was significantly lower in the group aged 51-70 compared to other age groups $(p=0.05)$ and in the group with vocational education compared to those with secondary and higher education $(\mathrm{p}<0.001)$. Only $49 \%$ of people $43 \%$ of men and $55 \%$ of women, were aware that UV ultrafioletowego. Kolejnym celem pracy było wskazanie, która grupa osób uwzględniając płeć, wiek i wykształcenie posiada najlepszą wiedzę w tym temacie, a do której grupy powinny być skierowane programy edukacyjne.

\section{MATERIAŁ I METODY}

Badanie zostało przeprowadzone w 2017 roku wśród 169 mieszkańców jednego z miast w województwie śląskim. Szczegółowa charakterystyka badanej grupy przedstawiona została $\mathrm{w}$ tabeli 1 . W badaniu posłużono się metodą sondażu diagnostycznego wykorzystując specjalnie do tego celu skonstruowaną autorską anonimową ankietę. Pierwsza część kwestionariusza składała się z pytań dotyczących płci badanych osób, ich wieku oraz wykształcenia. W celu określenia stopnia ekspozycji na promieniowanie UV, ankietowanych zapytano, czy spędzają czas na świeżym powietrzu przy słonecznej pogodzie oraz czy korzystają z solarium. Przy odpowiedzi twierdzącej proszono o podanie częstotliwości i długości ekspozycji. Pytano również o częstość stosowania preparatów promieniochronnych. Dalsza część ankiety składała się z 11 pytań zamkniętych jednokrotnego wyboru, 4 pytań z możliwością wybrania więcej niż jednej poprawnej odpowiedzi oraz dwóch pytań otwartych (źródła z których ankietowani czerpią wiedzę na temat promieniowania UV oraz główne kryterium którym kierują się przy zakupie okularów przeciwsłonecznych). Pytania dotyczyły podstawowych różnic pomiędzy zakresem UVA i UVB, znajomości pozytywnych i negatywnych skutków ich działania oraz działań profilaktycznych w trakcie przebywania na słońcu. W badaniu zastosowano analizę statystyczną opisową, a wyniki zaprezentowano w skali procentowej. Wartość procentowa była liczona w stosunku do całkowitej liczby odpowiedzi udzielonych przez respondentów na zadane pytanie. Do analizy statystycznej zastosowano test niezależności chi ${ }^{2}\left(\chi^{2}\right)$. Wyniki znamienne statystycznie uznano na poziomie $\mathrm{p} \leq 0,05$.

\section{WYNIKI}

34\% badanej grupy (58 osób) deklarowało, że nie spędza czasu na wolnym powietrzu podczas słonecznej pogody w okresie wiosenno-letnim. Większość pozostałej części grupy (111 osób), wśród których było, 48 mężczyzn i 63 kobiety przebywanie na słońcu ogranicza do okresu urlopowego lub wakacyjnego. 4 osoby spędzają na słońcu około 30 minut dziennie kolejne 4 osoby około 1 godziny dziennie, a u jednej osoby jest to aż 6 godzin dziennie, co może być związane $\mathrm{z}$ wykonywaną pracą. W grupie badanej korzystanie z solarium zadeklarowało 16 osób ( $9 \%$ respondentów), w tym 4 mężczyzn i 12 kobiet $(\mathrm{p}<0,05)$. Kosmetyki przeciwko promieniowaniu stosuje zdecydowanie większa liczba kobiet niż mężczyzn. Odsetek kobiet i mężczyzn stosujących takie kosmetyki zawsze wy- 
radiation triggers the production of melanin, a natural sunscreen. The correct answer was indicated by $76 \%$ of respondents in the under 35 age group, $35 \%$ of the group aged $36-50$ and only $21 \%$ of the oldest age group $(\mathrm{p}<0.001)$. The number of correct answers also depended on the level of education, $56 \%$ of people with secondary education, $48 \%$ of people with higher education and only $20 \%$ of those with the lowest education answered correctly $(\mathrm{p}<0.05)$. Only $17 \%$ of respondents were aware that UV inhibit the skincolonizing microorganisms activity. This response was indicated by $24 \%$ of the youngest group, $10 \%$ of the middle-aged group and $11 \%$ of the oldest group. However, there were no statistically significant differences depending on age, gender and level of education. $36 \%$ of respondents correctly answered the question about the possibility of reducing dermatoses symptoms, such as: psoriasis, atopic dermatitis, or lichen planus by UVR. This answer was marked by $15 \%$ of men and $55 \%$ of women $(\mathrm{p}<0.001)$.

Only $38 \%$ of respondents were aware which type of UVR was responsible for the sunburn, and the correct answer, "UVB, because the shorter the wavelength, the stronger the erythema reaction" was indicated statistically more often by women than men, people under 35 years of age and those with secondary education. Nearly half $(49 \%)$ of respondents did not know which UV range penetrated deeply into the skin, passed through the epidermis, reached the dermis and caused photoaging. The correct answer: "UVA, because the UV penetration depth into skin tissue is proportional to the wavelength" was more often indicated by women and people under 35 years of age. Respondents did not know which type of radiation was emitted by solarium. Only $27 \%$ were aware that, the strengthened UVA radiation with the limited UVB emission to reduce the erythema reaction, was a right answer. Table 2 shows the percentage of correct answers among questions about differences between UVA and UVB depending on respondent's gender, age and level of education.

The studied subjects were asked about their familiarity with photo-aging symptoms, i.e. chronic sun-damaged skin. $68 \%$ of respondents correctly indicated a uneven skin pigmentation, women $(p<0.001)$ definitely chose this answer much more often than men. $62 \%$ indicated the loss of skin firmness as a result of decreased collagen synthesis and in this question also women $(p<0.001)$ and people under 35 years of age have presented better knowledge. Other symptoms of photoaging like: small dilated blood vessels (teleangiectasias), thickening of the stratum corneum or sebaceous glands hypertrophy (comedones) were indicated by $30 \%, 27 \%$ and $13 \%$, respectively. niósł odpowiednio: $8 \%$ i $0 \%$; często $39 \%$ i $5 \%$; rzadko $50 \%$ i $85 \%$; nigdy $3 \%$ i $10 \%$.

Ankietowanych zapytano o znajomość pozytywnych skutków wynikających z działania promieniowania UV na skórę. 88\% mężczyzn i 92\% kobiet zaznaczyło, że zaliczamy do nich syntezę witaminy $\mathrm{D}_{3}$. Częstość wskazywania tego efektu była istotnie statystycznie mniejsza w grupie w przedziale wiekowym 51-70 lat w porównaniu do pozostałych grup wiekowych $(p=0,05)$ oraz $w$ grupie z najniższym wykształceniem w porównaniu do osób $\mathrm{z}$ wykształceniem średnim i wyższym $(\mathrm{p}<0,001)$. O fakcie, iż promieniowanie UV uaktywnia produkcję melaniny, będącej naturalnym filtrem przeciwsłonecznym, wiedziało tylko $49 \%$ osób - $43 \%$ mężczyzn i $55 \%$ kobiet. Odpowiedź taką wskazało $76 \%$ ankietowanych w grupie do $35 \mathrm{r}$. życia, $35 \%$ grupy z przedziału $36-50$ lat i zaledwie $21 \%$ grupy najstarszej $(\mathrm{p}<0,001)$. Na liczbę poprawnych wskazań tego pozytywnego efektu działania UV wpływ miało również wykształcenie respondentów, odpowiedź taką zaznaczyło 56\% osób z wykształceniem średnim, $48 \%$ osób z wykształceniem wyższym i zaledwie $20 \%$ badanych z najniższym wykształceniem $(\mathrm{p}<0,05)$. Jedynie $17 \%$ badanych wiedziało, że promienie ultrafioletowe hamują aktywność kolonizujących skórę drobnoustrojów. Odpowiedź tę zaznaczyło $24 \%$ osób z grupy najmłodszej, $10 \%$ grupy w średnim wieku i 11\% grupy najstarszej. Nie stwierdzono jednak znamiennych statystycznie różnic w zależności od wieku, płci i wykształcenia. Na możliwość łagodzenia przez promieniowanie UV objawów dermatoz takich jak: łuszczyca, atopowe zapalenie skóry, czy liszaj płaski, wskazało 36\% badanych. Odpowiedź tę zaznaczyło 15\% ankietowanych mężczyzn i 55\% kobiet $(\mathrm{p}<0,001)$.

Jedynie 38\% badanych było świadomych, który rodzaj promieniowania UV odpowiedzialny jest za powstanie oparzenia słonecznego, a prawidłową odpowiedź „UVB, ponieważ im krótsza dlugość fali, tym działanie rumieniotwórcze jest silniejsze" statystycznie częściej wskazywały kobiety niż mężczyźni, osoby przed 35. rokiem życia oraz posiadające wykształcenie średnie. Blisko połowa (49\%) respondentów nie wiedziała, jaki zakres widma UV przenika w największym stopniu przez naskórek do skóry właściwej powodując jej starzenie. Poprawną odpowiedź: „UVA, gdyż gtębokość przenikania UV do skóry jest wprost proporcjonalna do dtugości fali" częściej wskazywały kobiety oraz osoby które nie ukończyły 35. r. życia. Respondenci nie wiedzieli, który rodzaj promieniowania emitowany jest przez urządzenia solaryjne. Zaledwie $27 \%$ wskazało, że jest to wzmocnione promieniowanie UVA z ograniczeniem emisji UVB dla ograniczenia reakcji rumieniowej. Tabela 2 przedstawia procent poprawnych odpowiedzi na pytania dotyczące różnic pomiędzy UVA i UVB w zależności od płci, wieku i wykształcenia badanych osób. 
Table II. The knowledge of basic differences between UVA and UVB radiation depending on the gender, age and education level of the respondents.

Tabela II. Znajomość podstawowych różnic pomiędzy promieniowaniem UVA i UVB w zależności od płci, wieku i wykształcenia respondentów.

\begin{tabular}{|c|c|c|c|c|c|c|}
\hline \multirow[b]{2}{*}{ females } & \multicolumn{2}{|c|}{$\begin{array}{l}\text { Which type of UVR is } \\
\text { responsible for sunburn? }\end{array}$} & \multicolumn{2}{|c|}{$\begin{array}{l}\text { Which type of UVR is } \\
\text { responsible for photoaging? }\end{array}$} & \multicolumn{2}{|c|}{$\begin{array}{l}\text { Which type of UVR is } \\
\text { emitted by solariums? }\end{array}$} \\
\hline & $49 \%$ & \multirow{2}{*}{$\mathbf{p}<\mathbf{0 , 0 1}$} & $64 \%$ & \multirow{2}{*}{$\mathbf{p}<\mathbf{0 , 0 0 1}$} & $31 \%$ & \multirow{2}{*}{$\mathrm{p}>0,05$} \\
\hline males & $26 \%$ & & $38 \%$ & & $24 \%$ & \\
\hline age: $20-35$ & $54 \%$ & \multirow{3}{*}{$\mathbf{p}<\mathbf{0 , 0 0 1}$} & $64 \%$ & \multirow{3}{*}{$\mathbf{p}<\mathbf{0 , 0 1}$} & $41 \%$ & \multirow{3}{*}{$\mathbf{p}<\mathbf{0 , 0 0 1}$} \\
\hline age: $36-50$ & $27 \%$ & & $46 \%$ & & $27 \%$ & \\
\hline age: $51-70$ & $23 \%$ & & $36 \%$ & & $6 \%$ & \\
\hline higher education & $23 \%$ & \multirow{3}{*}{$\mathbf{p}<\mathbf{0 , 0 1}$} & $45 \%$ & \multirow{3}{*}{$\mathrm{p}>0,05$} & $23 \%$ & \multirow{3}{*}{$\mathrm{p}>0,05$} \\
\hline secondary education & $51 \%$ & & $57 \%$ & & $31 \%$ & \\
\hline vocational education & $25 \%$ & & $40 \%$ & & $20 \%$ & \\
\hline
\end{tabular}

The knowledge about the definition of free radicals also been tested. $44 \%$ of respondents knew that free radicals were reactive molecules and its formation was inducted by UVR. The majority of correct answers appeared in the under 35 years of age group compared to other age groups ( $\mathrm{p}<0.001)$. About $49 \%$ of the studied group knew about DNA oxidative damages caused by free radicals $(40 \%$ male and $56 \%$ female respondents $(p<0.05))$. The majority of correct answers appeared again in the youngest age group (64\%) compared with those from the middle aged group (42\%) and the oldest group $(32 \%) \quad(p<0.01)$. Statistically significant less correct answers about free radicals appeared among respondents with vocational education level. 14\% wrongly assumed that free radicals brought a beneficial effect on human body, $17 \%$ indicated that free radicals slowed the aging process. The use of cosmetics and supplements with vitamins $\mathrm{A}, \mathrm{C}$ and $\mathrm{E}$, in order to eliminate negative UV effects, was declared by 109 people (64\% of the studied group). Among those, 36 people did not present proper knowledge about free radicals.

$55 \%$ of studied people were not able to find the correct meaning of SPF abbreviation (Sun Protective Factor). $44 \%$ of men and $46 \%$ of women knew that it helped to calculate how much time the individual might stay in the sun without erythema reaction. $83 \%$ of men and $92 \%$ of women were aware that cosmetics with the SPF $50+$ did not provide $100 \%$ of the UV protection. Only $1 / 4$ of the studied group knew that the SPF only referred to the reduced level of UVB reaching the skin, and did not limit the UVA radiation at all. In this question, women presented better knowledge than men: respectively $15 \%$ vs $34 \%$ of correct answers $(p<0.01)$. Table 3 shows the percentage of correct answers regarding SPF factor depending on the age and level of education among respondents.

In the question: "Do you think that people with phototype III are less exposed to UVR compared to
Ankietowanych zapytano o znajomość objawów fotostarzenia, czyli przewlekłego posłonecznego uszkodzenia skóry. $68 \%$ badanych prawidłowo wskazało na nierównomierną pigmentację, przy czym zdecydowanie częściej tę odpowiedź wybierały kobiety $(\mathrm{p}<0,001) .62 \%$ wskazało utratę jędrności skóry w wyniku zmniejszonej produkcji kolagenu i tu również lepszą wiedzą wykazały się kobiety $(p<0,001)$ oraz osoby przed 35 r. życia. Pozostałe objawy fotostarzenia: poszerzenie naczyń krwionośnych skóry (teleangiektazje), pogrubienie warstwy rogowej naskórka i przerost gruczołów łojowych (zaskórniki) wskazało odpowiednio 30\%, 27\% i 13\% badanych. Sprawdzona została również wiedza ankietowanych na temat wolnych rodników. O tym, że są to reaktywne cząsteczki lub atomy, źródłem których jest m.in. promieniowanie UV wiedziało $44 \%$ respondentów. Najwięcej poprawnych odpowiedzi padło w grupie osób do 35. r. życia w porównaniu do pozostałych grup wiekowych $(\mathrm{p}<0,001)$. O tym, że wolne rodniki przyczyniają się do degeneracji DNA wiedziało $49 \%$ badanej grupy $(40 \%$ mężczyzn i $56 \%$ kobiet $(\mathrm{p}<0,05))$. Najwięcej poprawnych wskazań było w grupie najmłodszej $(64 \%)$ w porównaniu do grupy w średnim wieku $(42 \%)$ i najstarszej $(32 \%)(p<0,01)$. Osoby $z$ wykształceniem zawodowym na oba pytania dotyczące wolnych rodników udzieliły istotnie statystycznie mniej dobrych odpowiedzi niż pozostałe grupy wykształcenia. 14\% grupy badanej błędnie podało, że wolne rodniki mają korzystny wpływ na organizm, a 17\% zaznaczyło, że spowalniają starzenie. Stosowanie kosmetyków i suplementów diety z zawartością witamin A, C i E w celu niwelowania niekorzystnych skutków UV zadeklarowało 109 osób (64\% badanej grupy). Wśród nich prawidłowej wiedzy na temat wolnych rodników nie posiadało 36 osób.

$55 \%$ badanych nie znało znaczenia skrótu SPF (Sun Protective Factor). 44\% mężczyzn i 46\% kobiet wiedziało, że pozwala on na osobnicze obliczenie czasu, jaki można przebywać na słońcu bez wystąpienia reakcji rumieniowej. $83 \%$ mężczyzn i $92 \%$ kobiet było świadomych, że preparaty z filtrem SPF 50+ nie blokują 
people with phototype II" the correct answer "yes" was indicated only by $33 \%$ of people, at the same time many respondents - 91 people (54\%) indicated "I do not know." Women showed better knowledge of the meaning of skin phototype - $44 \%$ gave an correct answer compared to $23 \%$ of men $(\mathrm{p}<0.01)$. The group aged 51-70 gave statistically significant less right answers compared to other age groups $(\mathrm{p}<0.05)$. w 100\% docierania promieni UV do skóry. Tylko $1 / 4$ badanej grupy wiedziała, że współczynnik SPF świadczy jedynie o stopniu ograniczenia przez dany preparat dostępu promieniowania UVB do skóry, nie dotyczy natomiast ograniczenia promieniowania UVA. W pytaniu tym lepszą wiedzą w porównaniu do mężczyzn wykazały się kobiety: odpowiednio $15 \%$ vs $34 \%$ poprawnych wskazań $(p<0,01)$. Tabela III przedstawia procent poprawnych odpowiedzi dotyczących współczynnika SPF w zależności od wieku i wykształcenia respondentów.

Table III. The percentage of correct answers regarding SPF depending on the age and level of education among respondents. Tabela III. Procent poprawnych odpowiedzi dotyczących współczynnika SPF w zależności od wieku i wykształcenia respondentów.

\begin{tabular}{|c|c|c|c|c|c|c|}
\hline & \multicolumn{2}{|c|}{$\begin{array}{l}\text { Meaning of SPF } \\
\text { abbreviation }\end{array}$} & \multicolumn{2}{|c|}{ Interpretation of SPF $50+$} & \multicolumn{2}{|c|}{$\begin{array}{c}\text { Type of UVR limited by } \\
\text { SPF }\end{array}$} \\
\hline age: $20-35$ & $55 \%$ & \multirow{3}{*}{$\mathrm{p}<0,01$} & $88 \%$ & \multirow{3}{*}{$\mathbf{p}<\mathbf{0 , 0 1}$} & $32 \%$ & \multirow{3}{*}{$\mathrm{p}>0,05$} \\
\hline age: $36-50$ & $50 \%$ & & $86 \%$ & & $19 \%$ & \\
\hline age: $51-70$ & $23 \%$ & & $64 \%$ & & $19 \%$ & \\
\hline higher education & $43 \%$ & \multirow{3}{*}{$\mathbf{p}<0,05$} & $83 \%$ & \multirow{3}{*}{$\mathbf{p}<0,05$} & $20 \%$ & \multirow{3}{*}{$\mathrm{p}>0,05$} \\
\hline secondary education & $52 \%$ & & $83 \%$ & & $29 \%$ & \\
\hline vocational education & $20 \%$ & & $60 \%$ & & $20 \%$ & \\
\hline
\end{tabular}

Nearly $100 \%$ of answerers knew at what time of a day the direct sunlight should be avoided during summer. Only one person participating in the study reported that the time of day was irrelevant. $44 \%$ correctly indicated the amount of sunscreen recommended to apply to a skin for a proper UV protection $\left(2 \mathrm{mg} / \mathrm{cm}^{2}\right)$. $15 \%$ chose the $5 \mathrm{mg} / \mathrm{cm}^{2}$, while insufficient amounts: $0.05 \mathrm{mg} / \mathrm{cm}^{2}$ and $0.5 \mathrm{mg} / \mathrm{cm}^{2}$ were indicated by $10 \%$ and $31 \%$ answerers respectively. $71 \%$ of people, regardless of gender, age and level of education, were aware of the necessity to re-apply even the waterproof sunscreens after bathing. Respondents were also asked about the opinion of the legitimacy of using UV-protective cosmetics on sun exposed body parts throughout the whole year. $36 \%$ of respondents believed that they should be applied. This opinion was expressed by $20 \%$ of men and $52 \%$ of women ( $<<0.001)$, as well as $53 \%$ of people under 35 years of age, $21 \%$ from the middle age group and $26 \%$ of the oldest group $(p<0.01)$. Additionally, there were also a comparison whether those people who had answered "yes" for previous question also knew that SPF informed just about protection against UVB. Only half women (22) were aware, while in the men group no one answered correctly.

The true definition of melanoma was chosen by nearly half of respondents. Those who indicated all possibilities ( 7 people), or the right answer together with a wrong one ( 9 people), despite clearly asking for only one answer, were not considered as aware. Those people together with two others, who did not indicate any answer were classified to the group without
Na pytanie: „Czy uważa Pani/Pan, że osoby o fototypie III sq $w$ mniejszym stopniu narażone na promieniowanie $U V w$ porównaniu do osób o fototypie II' odpowiedzi twierdzącej udzieliło zaledwie 33\% ankietowanych, natomiast aż 91 osób (54\% badanych) zaznaczyło odpowiedź: „Nie wiem.” Lepszą wiedzą na temat fototypu skóry wykazały się kobiety - odpowiedzi twierdzącej udzieliło 44\% w porównaniu do 23\% mężczyzn $(\mathrm{p}<0,01)$. Grupa osób w przedziale wiekowym 51-70 lat udzieliła na to pytanie istotnie statystycznie mniej dobrych odpowiedzi w porównaniu do pozostałych grup wiekowych $(\mathrm{p}<0,05)$.

Blisko $100 \%$ respondentów wiedziało, w jakich godzinach należy unikać bezpośredniego nasłonecznienia w okresie letnim. Tylko jedna osoba uczestnicząca w badaniu podała, że pora dnia nie ma znaczenia. $44 \%$ ankietowanych prawidłowo wskazało ilość preparatu promieniochronnego, jaką należy nałożyć na skórę, aby spełniał swoją funkcję $\left(2 \mathrm{mg} / \mathrm{cm}^{2}\right) .15 \%$ badanych wybrała odpowiedź $5 \mathrm{mg} / \mathrm{cm}^{2}$, natomiast niewystarczające ilości preparatu: $0,05 \mathrm{mg} / \mathrm{cm}^{2}$ i $0,5 \mathrm{mg} / \mathrm{cm}^{2}$ wskazało odpowiednio $10 \%$ i $31 \%$ osób. $71 \%$ badanych osób bez względu na płeć wiek i wykształcenie było świadomych konieczności ponownego nałożenia na skórę preparatu wodoodpornego po kąpieli. Respondentów zapytano również o opinię na temat zasadności stosowania kosmetyków promieniochronnych na nieosłonięte części ciała w ciągu całego roku. 36\% badanych jest zdania, że powinny być one stosowane. Opinię taką wyraziło $20 \%$ mężczyzn i $52 \%$ kobiet $(\mathrm{p}<0,001)$, jak również $53 \%$ osób do 35 . r. życia, $21 \%$ średniej grupy wieko- 
knowledge in this subject. The correct definition of melanoma was chosen by $37 \%$ of men and $64 \%$ of women $(\mathrm{p}<0.001)$, by $56 \%$ of people with higher education, $55 \%$ with secondary education and only $10 \%$ of people with vocational education $(\mathrm{p}<0.001)$. The percentage of people indicating particular melanoma definitions is shown in figure 1 . The respondents were asked to define the main selection criteria while buying sunglasses. The most frequent answer among 100 people (59\% of the surveyed group) were the affordable price, the aesthetics and the current fashion. The smaller group of respondents - 64 people (38\%) paid attention to sunscreens and buy sunglasses mainly in optometrist. Two people admitted not wearing glasses at all, without giving any reason, and other three did not answer the question.

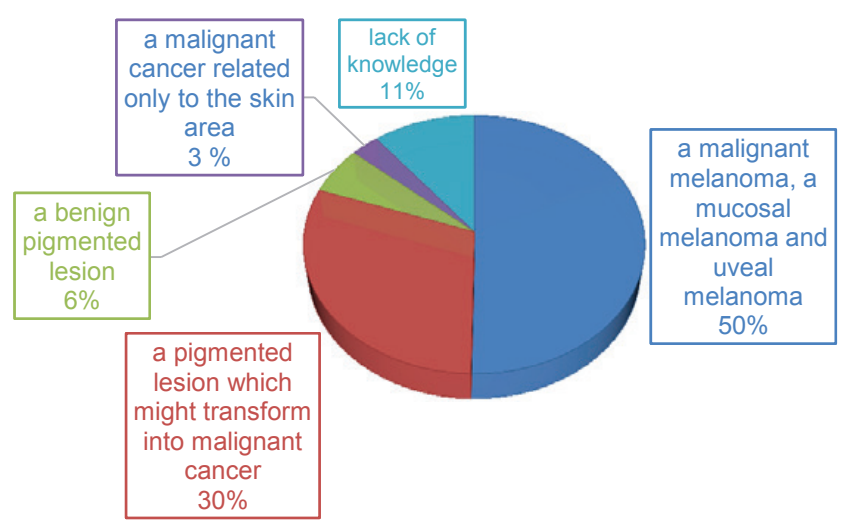

Fig. 1. The respondents' knowledge about the definition of melanoma.

Ryc. 1. Wiedza ankietowanych dotycząca definicji czerniaka

\section{DISCUSSION}

The UV spectrum, as a part of electromagnetic radiation that reaches Earth's surface, has effects both beneficial and harmful to human health. In the present study, the vitamin D synthesis was indicated most often among all beneficial effects of UVR. To cover $90 \%$ of daily required amount of vitamin $\mathrm{D}$ production in the skin, $15 \%$ of the skin surface must be exposed to the sun for about $1 / 4$ of the time required to cause a slight redness. This amount of time varies according to the complexion or number of melanin particles in the skin. In Poland (latitude above $34^{\circ} \mathrm{N} / \mathrm{S}$ ) this opportunity arises from April to September, provided that there is no cloud cover. While $90 \%$ of the study group were aware of the role of ultraviolet in the vitamin D formation, about $1 / 3$ admitted to not spending time in the sun. Other respondents sunbath only during the holiday period, comments like "I avoid sun" or "I always look for shady places" appeared very often. Only 9 people declared daily sun exposures. Melanin - natural photoprotection, is not known by half of the studied wej i $26 \%$ najstarszej grupy $(p<0,01)$. Dodatkowo porównano ile osób, które odpowiedziały twierdząco na to pytanie wiedziało, że faktor SPF informuje o ochronie tylko przed promieniami UVB. Świadoma tego faktu była zaledwie połowa grupy kobiet (22 osoby) natomiast $\mathrm{w}$ grupie mężczyzn nikt nie udzielił prawidłowej odpowiedzi odnośnie SPF.

Prawidłową definicję czerniaka wybrała blisko $1 \frac{1}{2}$ ankietowanych. Osobom, które pomimo prośby o wybranie tylko jednej poprawnej odpowiedzi wskazały wszystkie możliwości (7 osób), bądź odpowiedź właściwą wraz $\mathrm{z}$ jedną odpowiedzią błędną ( 9 osób), nie uznano odpowiedzi jako poprawnej. Ankietowani ci razem z dwiema osobami, które nie zaznaczyły żadnej odpowiedzi zaklasyfikowani zostali do grupy nieposiadającej wiedzy na ten temat. Prawidłową definicję czerniaka wybrało 37\% grupy mężczyzn i $64 \%$ grupy kobiet $(\mathrm{p}<0,001)$ oraz $56 \%$ osób z wykształceniem wyższym, $55 \%$ z wykształceniem średnim i zaledwie $10 \%$ osób posiadających wykształcenie zawodowe $(p<0,001)$. Odsetek osób wskazujących daną definicję czerniaka prezentuje rycina 1 .

Osoby badane zostały poproszone o podanie głównego kryterium, jakim kierują się kupując okulary przeciwsłoneczne. Do najczęściej wymienianych odpowiedzi u 100 osób (59\% badanej grupy) należało min. przystępna cena, estetyka i aktualna moda. Mniejsza grupa ankietowanych - 64 osoby (38\%) zwracały uwagę, czy okulary posiadają filtry przeciwsłoneczne i kupuje je głównie w zakładach optycznych. Dwie osoby oświadczyły, że nie kupują okularów nie podając powodów takiego postępowania, a trzy osoby nie udzieliły odpowiedzi na to pytanie.

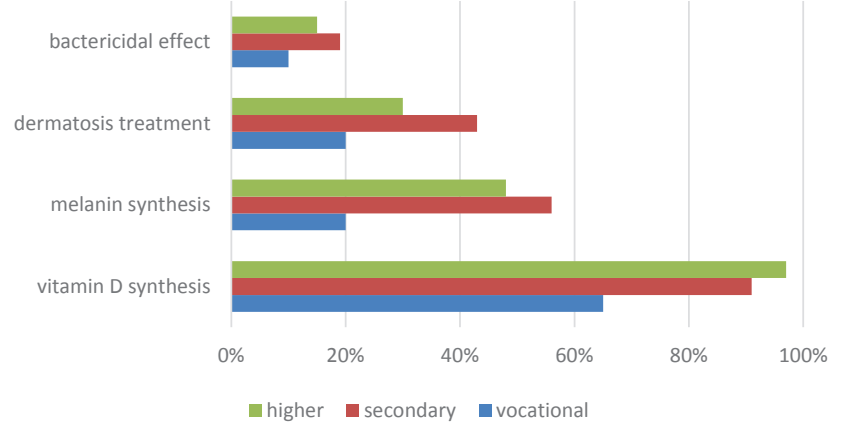

Fig. 2. The respondents' knowledge about the positive effects of UV radiation depending on educational level

Ryc. 2. Wykształcenie a wiedza ankietowanych dotycząca korzystnych efektów promieniowania UV.

\section{DYSKUSJA}

Widmo ultrafioletu, stanowiące część docierającego do Ziemi promieniowania elektromagnetycznego, wywiera na organizmy żywe efekty zarówno pozytywne jak i negatywne. W niniejszym badaniu spośród wszystkich 
group. Melanin particles accumulate in the cell nucleus of keratinocytes, in lower layers of the epidermis, absorbing UVB and UVA radiation thus protecting the DNA against photodamage and neutralizing free radicals. Female and younger respondents had better knowledge about beneficial effects of UVR.

The penetration depth of the electromagnetic radiation in tissue is proportional to the wavelength, whereas the higher the energy of radiation the shorter the wavelength. UVB is almost completely absorbed by stratum corneum - the outermost layer of the epidermis, only $20 \%$ reaches the basal layer, while UVA with the longest wavelength penetrates to the dermis. In the current study, nearly $1 / 3$ of the answerers were aware that UVB radiation was responsible for the appearance of a sunburn, i.e. the ultravioletinduced erythema reaction, while half of the study group was aware what type of UVR penetrates into the dermis. Torzewska et al. (6) showed that only $15 \%$ respondents provided correct answer about UVA radiation, while Flis et al. (7) while assessing the awareness of photoaging and photoprotection among inhabitants of the Podkarpackie province, demonstrated that $79 \%$ of respondents did not know the basic differences between UVA and UVB. The fact that in the current study only $9 \%$ of respondents use the solarium was the manifestation of raising public awareness of health risk for taking such actions. For comparison, in Glinska et al. (8) study form 2009, $54.2 \%$ of answerers used solarium, and in Torzewska et al. (6) survey conducted in 2014 among residents of the Łódź region, the percentage decreased to $36 \%$. Unfortunately, the knowledge about the type of radiation emitted by solarium is insufficient. At the turn of the year 1989/1990, the UVA radiation power in solariums was increased by 10 times its natural value in the sunlight. In the present study, less than $1 / 3$ of the respondents knew that during solarium session skin was exposed for UVA with a reduction of UVB emission to minimize the ultraviolet-induced erythema reaction. Among 16 people who admitted to using solarium, only 2 provided the correct answer. For comparison, in the study of Krajewska-Kulak et al. (9) $34.5 \%$ of students from Łomża connected sunbathing in the solarium with both UVA and UVB, and the group of nurses and midwives examined by Glińska's group (8) provided $42.5 \%$ correct answers.

The most dangerous effect of UVR is melanomaa malignant tumor of the skin, mucous membrane or uveal tract of the eye. In Torzewska's study (6), the $60 \%$ of the studied group was aware that pigmented lesions may lead to skin cancer, while in KrajewskaKułak study (9), only 43 out of 229 surveyed students connected tanning in the solarium with the risk of neoplastic changes. In this study, the correct definition korzystnych skutków promieniowania UV ankietowani najczęściej wskazywali na syntezę witaminy D. Do powstania tej witaminy w organizmie w ilości pokrywającej $90 \%$ jej dobowego zapotrzebowania wystarcza ekspozycja około $15 \%$ powierzchni ciała (odsłonięta twarz, przedramiona i dłonie) wynosząca $1 / 4$ czasu wymaganego do wywołania lekkiego zaróżowienia skóry. Czas ten różni się w zależności od karnacji, czy też ilości melaniny w skórze. W Polsce (szerokość geograficzna powyżej $34^{\circ} \mathrm{N} / \mathrm{S}$ ) taka możliwość istnieje od kwietnia do września pod warunkiem braku zachmurzenia. Pomimo tego, że $90 \%$ badanej grupy było świadomych roli ultrafioletu w powstawaniu witaminy $\mathrm{D}, \mathrm{az} 1 / 3$ ankietowanych przyznała, że nie spędza czasu na słońcu. Pozostałe osoby poddają się ekspozycji słonecznej jedynie w trakcie urlopu, a komentarze typu „unikam stońca” lub ,szukam cienia" pojawiały się bardzo często. Zaledwie 9 osób deklaruje stałe, dzienne ekspozycje. Połowa ankietowanej grupy nie wiedziała o powstającej pod wpływem UV naturalnej fotoprotekcji - melaninie. Melanina gromadząc się nad jądrem komórkowym keratynocytów w dolnych warstwach naskórka pochłania promieniowanie UVB i UVA chroniąc tym samym DNA przed fotouszkodzeniem, neutralizuje również wolne rodniki. Większą wiedzę na temat korzystnych skutków promieniowania UV posiadały kobiety i osoby z grupy najmłodszej.

Głębokość przenikania fali elektromagnetycznej do tkanki jest proporcjonalna do długości fali natomiast energia promieniowania jest tym większa, im długość fali krótsza. Większa cześć promieniowania UVB pochłaniana jest przez najbardziej zewnętrzną warstwę naskórka, warstwę rogową, a jedynie $20 \%$ dociera do warstwy podstawnej, podczas gdy promieniowanie o dłuższej fali - UVA, penetruje aż do skóry właściwej. Blisko $1 / 3$ ankietowanych $\mathrm{w}$ obecnym badaniu wiedziała, że promieniowanie UVB odpowiedzialne jest za pojawienie się oparzenia słonecznego, czyli ostrego odczynu rumieniowo-zapalnego, natomiast połowa badanej grupy była świadoma, jaki rodzaj promieniowania UV przenika przez naskórek do skóry właściwej. W badaniach $T o$ rzewskiej i wsp. (6) zaledwie $15 \%$ badanych poprawnie wskazało na promieniowanie UVA, natomiast w pracy Flis i wsp. (7) oceniającej świadomość mieszkańców województwa podkarpackiego na temat fotostarzenia i fotoprotekcji, aż 79\% badanych nie znało podstawowych cech różniących UVA i UVB.

Za zwiększeniem świadomości społeczeństwa odnośnie zagrożeń związanych z naświetlaniem skóry w solariach przemawia fakt, iż w niniejszym badaniu korzystało z solarium jedynie $9 \%$ respondentów. Dla porównania w badaniach Glińskiej i wsp. (8) z 2009 roku z tego typu usług korzystało $54,2 \%$ ankietowanych a w badaniach $T o$ rzewskiej i wsp. (6) przeprowadzonych w 2014 roku wśród mieszkańców województwa łódzkiego odsetek ten zmalał do $36 \%$. Niestety wiedza ankietowanych na temat rodzaju 
of melanoma was known by half of respondents. Women again have shown better knowledge. Among people with higher education $46 \%$ did not provide a correct answer, comparable to people with secondary education (45\% incorrect answers). Even fewer respondents were aware of harmful effects of ultraviolet on the organ of sight. Only $38 \%$ of the surveyed group paid attention to sunscreens while buying sunglasses.

The possible limitations of negative health effects of UV exposure as a result of some prevention actions were also assessed. All respondents were aware of the time of the day at which the direct sunlight should be avoided, with the exception of one person. In the group of nurses and midwives (8) as well as in the group of students studied by Krajewska-Kułak et al. (9), the frequency of correct answers was significantly lower and amounted $36.7 \%$ and $24.5 \%$, respectively. In this study, women were more concerned about photoprotection and used sunscreens much more often than men (39\% vs. $5 \%)$. Zalewska et al. (10) confirmed this observation, the frequent using of sunscreens was declared by $28 \%$ of women and only $1 \%$ of men. The amount of sunscreen recommended by FDA (The Food and Drug Administration in USA) to apply to the skin for a UV protection is greater than or equal to $2 \mathrm{mg} /$ $\mathrm{cm}^{2}$. In present study, $59 \%$ of respondents indicated correct answers: $2 \mathrm{mg} / \mathrm{cm}^{2}$ and $5 \mathrm{mg} / \mathrm{cm}^{2}$, comparable to Glińska's (8) results (51.7\%), whereas in Zalewska's study (10) only $8 \%$ of answerers knew how much sunscreen should be applied to the skin surface. Regardless of gender, age and level of education, $71 \%$ of people were aware of the necessity of the re-applying even the waterproof sunscreen after bathing, sweating or wiping off, similarly to $95 \%$ of Warsaw high school students (11). More than half of the respondents was not aware of the meaning of the SPF abbreviation commonly found on sunscreen labels. People of the oldest age group and those with vocational education had the smallest knowledge, they also believed more often that SPF $50+$ provided a complete sun protection. Respondents, especially men and people in the oldest age group, were not able to differentiate the basic skin phototypes. Considering the limited knowledge about the melanin synthesis in the epidermis, the subjects were not aware that the more melanin particles in the skin, the longer the time allowed for sunbathing. This knowledge would be useful for selecting appropriate SPF factor in cosmetics for UV protection. 61 people (44 women and 17 men) use cosmetics with SPF all year long. Out of this group, only 22 women do so with the awareness of the importance of the SPF. In autumn and winter, when the duration of daylight becomes shorter, as well as during cloudiness, when the intensity of UVB is low, cosmetics with a low SPF factor and high UVA protection should be chosen. The emitowanego przez urządzenia solaryjne promieniowania jest niezadowalająca. Na przełomie lat 89. i 90 . XX wieku moc promieniowania UVA w solariach została zwiększona do wartości 10-krotnie przekraczającej jego zawartość w naturalnym świetle słonecznym. W niniejszym badaniu mniej niż $1 / 3$ respondentów wiedziała, że opalanie w solarium związane jest $\mathrm{z}$ naświetlaniem skóry promieniowaniem UVA z ograniczeniem emisji UVB dla zminimalizowania reakcji rumieniowej. Wśród 16 osób korzystających z solarium poprawnej odpowiedzi udzieliły jedynie 2 osoby. Dla porównania, w pracy Krajewskiej-Kułak i wsp. (9) 34,5\% badanych studentów z Łomży wiązało proces opalania w solarium zarówno z UVA, jak i UVB, a badana przez Glińska i wsp. (8) grupa pielęgniarek i położnych udzieliła 42,5\% poprawnych odpowiedzi.

Do największych zagrożeń związanych z promieniowaniem UV należy czerniak - nowotwór złośliwy skóry, błony śluzowej i błony naczyniowej oka. W badaniu Torzewskiej i wsp. (6) 60\% badanej grupy było świadomych, że zmiany barwnikowe mogą prowadzić do powstania nowotworu skóry, natomiast w pracy Krajewskiej-Kułak i wsp. (9) wśród 229 ankietowanych studentów jedynie 43 osoby wiązały opalanie $w$ solarium $\mathrm{z}$ ryzykiem wystąpienia zmian nowotworowych. W niniejszej pracy prawidłową definicję czerniaka wskazała połowa respondentów. Lepszą wiedzą ponownie wykazały się kobiety. Wśród osób z wykształceniem wyższym aż 46\% nie udzieliło poprawnej odpowiedzi, porównywalnie do osób posiadających wykształcenie średnie $(45 \%$ błędnych wskazań). Jeszcze mniejsza liczba ankietowanych zdawała sobie sprawę $z$ negatywnego działania ultrafioletu na narząd wzroku. Zaledwie 38\% badanej grupy przy zakupie okularów przeciwsłonecznych zwracała uwagę czy wyposażone są one w filtry przeciwsłoneczne.

Ocenione zostały również zachowania profilaktyczne badanej grupy, dzięki którym możliwe jest ograniczenie negatywnych skutków zdrowotnych wynikających z nadmiernej ekspozycji na UV. Z wyjątkiem jednej osoby, wszyscy ankietowani byli świadomi, w jakich godzinach należy unikać bezpośredniej ekspozycji słonecznej. W grupie pielęgniarek i położnych (8) oraz w grupie studentów badanych przez Krajewską-Kułak i wsp. (9) częstość poprawnych wskazań była zdecydowanie mniejsza i wynosiła odpowiednio: $36,7 \%$ i 24,5\%. W niniejszym badaniu kobiety bardziej dbają o fotoprotekcję stosując preparaty promieniochronne zdecydowanie częściej niż mężczyźni (39\% vs 5\%). Wyniki pracy Zalewskiej i wsp. (10) potwierdzają tą obserwację, częste stosowanie tych kosmetyków deklaruje 28\% kobiet i zaledwie 1\% mężczyzn. Zalecana przez FDA (Federalny Urząd Żywności i Leków w USA) dawka preparatu promieniochronnego wynosi $\geq 2 \mathrm{mg} / \mathrm{cm}^{2}$. W obecnym badaniu prawidłowe odpowiedzi: $2 \mathrm{mg} / \mathrm{cm}^{2}$ i $5 \mathrm{mg} / \mathrm{cm}^{2}$ wskazało łącznie $59 \%$ ankietowanych, porównywalnie do wyników Glińskiej i wsp. (8) (51,7\%), natomiast w badaniu Zalewskiej i wsp. (10) zaledwie 
prevention actions among $64 \%$ of respondents also included the use of cosmetics and dietary supplements with antioxidants, however, about $33 \%$ of this group did so unconsciously, without the basic knowledge about free radicals.

To sum up, the knowledge about UVR and its negative and positive effects is insufficient among respondents, and its level depended on gender, age and degree of education. Educational programs about negative effects of sunbathing or solarium, but also the promotion of daily short-term sun exposures in Polish society seem reasonable to implement. Vitamin D deficiency resulting from its insufficient dermal synthesis is difficult to supplement with diet because in natural food products there are very small amounts of vitamin $\mathrm{D}$. The overdose can occur from high intakes of supplements containing vitamin $\mathrm{D}$, but not from dietary intake or sunbathing. The correct use of cosmetics with sunscreens, especially those with a high SPF in the autumn and winter when skin synthesis is limited, should be also mentioned. In people who do not use sunscreens properly, paradoxical photoprotection may occur, as a result of an false sense of security. Those using sunscreens stays in the intense sun longer, not realizing that any sunscreen provides a complete sun protection.

\section{CONCLUSIONS}

1. Most respondents were aware of UVR value for the vitamin D synthesis. People of oldest age group and those with vocational level of education presented the smallest knowledge about the positive impact of UVR on a human body.

2. A small percentage of respondents declared healthy regular short-term sun exposures. The majority sunbath only during the holiday period. Respondents were aware of daytime when direct sunlight should be avoided and most of them do not use a solarium.

3. Women had definitely more knowledge about negative effects of ultraviolet than men, also use UV-filters more often. People of oldest age group and those with vocational education were not aware of the significance of the SPF abbreviation, they also believed that SPF $50+$ provided a complete sun protection.

4. The correct definition of melanoma was identified by half of respondents, mostly by females.

\section{REFERENCES}

1. Lucas R, McMichael T, Smith W, Armstrong B, Solar ultraviolet radiation. Global burden of disease from solar ultraviolet radiation. Environmental Burden of Disease 2006; 13: 1-87.
$8 \%$ ankietowanych wiedziało, jaką ilość preparatu należy nałożyć na skórę. $71 \%$ osób niezależnie od płci, wieku i wykształcenia wiedziało o konieczności ponownego nałożenia preparatu wodoodpornego po kąpieli, spoceniu się czy wytarciu skóry, dla porównania aż 95\% uczniów warszawskich szkół średnich było świadomych tego faktu (11). Ponad połowa badanych nie znała znaczenia skrótu SPF obecnego powszechnie na kosmetykach promieniochronnych. Najniższą wiedzę posiadały osoby z grupy najstarszej i z wykształceniem zawodowym, one to również częściej były przekonane, że faktor SPF 50+ całkowicie blokuje docieranie UV do skóry. Respondenci, zwłaszcza mężczyźni i osoby w najstarszej grupie wiekowej, nie potrafili rozróżnić podstawowych fototypów skóry. Biorąc pod uwagę niezadowalającą wiedzę na temat syntezy melaniny w naskórku, badane osoby nie były świadome, że im więcej barwnika znajduje się w skórze, tym czas przebywania na słońcu ulega wydłużeniu. Wiedza ta pozwolilaby na dobranie kosmetyku promieniochronnego z odpowiednim faktorem SPF. 61 osób badanych (44 kobiety i 17 mężczyzn) stosuje kosmetyki z filtrami przeciwsłonecznymi w ciągu całego roku. $Z$ grupy tej tylko 22 kobiety robią to świadomie znając znaczenie skrótu SPF. W trakcie krótkiego dnia w okresie jesienno-zimowym, jak i podczas zachmurzenia, gdy natężenie UVB jest niskie, należałoby wybrać preparat z niskim faktorem SPF i filtrami przeciwko promieniowaniu UVA. Do zachowań profilaktycznych wśród 64\% ankietowanych należało również stosowanie kosmetyków i suplementów diety z zawartością antyoksydantów, jednakże około 33\% tej grupy robi to nieświadomie, nie posiadając wiedzy na temat wolnych rodników.

Reasumując, wiedza ankietowanych na temat promieniowania UV oraz jego negatywnych i pozytywnych skutków jest niewystarczająca, a jej poziom zależny jest od płci, wieku i wykształcenia. Zasadne wydają się być programy edukacyjne dotyczące nie tylko negatywnych skutków kąpieli słonecznych, czy też opalania w solarium, ale również propagowanie wśród społeczeństwa polskiego krótkich dziennych ekspozycji na działanie światła słonecznego. Niedobory witaminy D, wynikające z niedostatecznej skórnej syntezy, trudno jest uzupełnić dietą, ponieważ naturalne produkty żywnościowe zawierają bardzo małe ilości tej witaminy. Stosowanie ogólnie dostępnych suplementów witaminy D wiąże się z ryzykiem przedawkowania, co nie ma miejsca podczas naturalnej syntezy na słońcu. Należy również położyć nacisk na prawidłowe stosowanie preparatów z filtrami przeciwsłonecznymi, zwłaszcza z wysokim faktorem SPF w okresie jesienno-zimowym, co ogranicza już i tak niewielką syntezę skórną. U osób niewłaściwie stosujących filtry przeciwsłoneczne może dojść do paradoksalnego efektu fotoprotekcji w wyniku pozornego poczucia bezpieczeństwa. Osoby używające fotoprotektorów dłużej przebywają na intensywnym słońcu nie zdając sobie sprawy, że żaden faktor nie blokuje promieniowania UV w $100 \%$. 
2. Tukaj C. Właściwy poziom witaminy D warunkiem zachowania zdrowia. Postępy Hig Med. Dosw 2008; 62: 502-510.

3. Kuryłowicz A, Bednarczuk T, Nauman J. Wpływ niedoboru witaminy D na rozwój nowotworów i chorób autoimmunologicznych. Endokrynol Pol 2007; 58: 140-152.

4. Bowszyc-Dmochowska M, Działanie promieniowania ultrafioletowego na skórę. Ostre i przewlekłe uszkodzenie posłoneczne. Homines Hominibus 2010; 6: 29-42.

5. Ferenc T, Pacholczyk M, Czernicki J. Wpływ słonecznego promieniowania ultrafioletowego (UV) na organizm człowieka. Część II: Mutagenne działanie promieniowania UV i naprawa uszkodzeń DNA. Acta Balneol 2014; 56: 82-87.

6. Torzewska K, Malinowska-Borowska J, Wypych-Ślusarska A, Zieliński G. Opalanie się w solarium - wiedza, postawa i nawyki Polaków. Medycyna Środowiskowa 2014; 17: 52-59.

7. Flis A, Pelc K, Zielińska K. Fotostarzenie - jak wiele o nim wiemy? ww.think.wsiz.rzeszow.pl, ISSN 20821107, 2011; 4: 62-70.

8. Glińska J, Krajewska-Kułak E, Szyszko-Perłowska A, Lewko J. Ocena wiedzy pielęgniarek i położnych na temat zasad korzystania z solarium. Probl Hig Epidemiol 2009; 90: 391-397.

9. Krajewska-Kułak E, Kowalewska B, Wróblewska K, Chilińska J, Gołębiewska A, Sobocińska A. Postawy studentów wobec korzystania z solarium i kąpieli słonecznych. Problemy Pielęgniarstwa 2011; 19: 322-328.

10. Zalewska A, Cylkowska-Nowak M. Zdrowa skóra a słońce - próba diagnozy wiedzy oraz wybranych postaw. Nowiny Lekarskie 2012; 81: 214-218.

11. Koczkodaj P, Sobol M, Badowska-Kozakiewicz AM. Ocena wiedzy uczniów warszawskich szkół średnich na temat skutków zdrowotnych wynikających z nadmiernego korzystania $\mathrm{z}$ promieniowania ultrafioletowego (UV). J Edu Health and Sport 2016; 6: 94-110.

\section{WNIOSKI}

1. Większość ankietowanych była świadoma, że korzystnym efektem promieniowania ultrafioletowego jest synteza witaminy $\mathrm{D}$, najmniejszą wiedzę na temat pozytywnego wpływu promieniowania UV na organizm posiadały osoby z najstarszej grupy wiekowej i te $\mathrm{z}$ wykształceniem zawodowym.

2. Tylko niewielki procent ankietowanych deklarował najkorzystniejsze dla zdrowia regularne krótkotrwałe ekspozycje na słońce, większość korzystała z kąpieli słonecznych podczas okresu urlopowego. Respondenci wiedzieli, w jakich godzinach należy unikać bezpośredniego nasłonecznienia i w większości nie korzystali z solarium.

3. Zdecydowanie większą wiedzę na temat niekorzystnych skutków ultrafioletu posiadały kobiety, one też częściej stosowały preparaty promieniochronne. Osoby z grupy najstarszej i posiadające wykształcenie zawodowe nie znały znaczenia skrótu SPF, a SPF 50+ kojarzyły z w pełni bezpiecznym przebywaniem na słońcu.

4. Połowa respondentów, $w$ tym większość stanowiły kobiety, znała prawidłową definicję czerniaka.

\author{
Received: 4.10.2018 \\ Accepted for publication: 6.11.2018 \\ Otrzymano: 4.10.2018 \\ Zaakceptowano do publikacji: 6.11.2018 r.
}

\author{
Address for correspondence: \\ Adres do korespondencji: \\ Dr n. med. Magdalena Kamińska \\ Katedra Podstawowych Nauk Biomedycznych \\ Śląski Uniwersytet Medyczny w Katowicach \\ tel. 322699830 \\ e-mail: mkaminska@sum.edu.pl
}

